\title{
An archaeothanatological approach to the study of Minoan funerary practices: Case-studies from the Early and Middle Minoan cemetery at Sissi, Crete
}

\author{
Isabelle Crevecoeur ${ }^{1}$, Aurore Schmitt ${ }^{2}$, Ilse Schoep ${ }^{3}$ \\ ${ }^{1}$ UMR 5199 PACEA, CNRS, Université de Bordeaux, Pessac, France, ${ }^{2}$ UMR 7268 ADES, CNRS, Aix Marseille \\ Université, Marseille, France, ${ }^{3}$ Onderzoekseenheid Archeologie, KU Leuven, Belgium
}

\begin{abstract}
Our understanding of Minoan funerary practices in the Early and Middle Bronze Age on Crete was until recently to a large degree informed by the excavations of cemeteries that took place early in the 20th century. However, the aforementioned excavations are characterized by a significant lack of detailed archaeological data regarding the precise positions of osteological remains and the actual treatment of the body. The excavation of the Early Minoan II-Middle Minoan II cemetery at Sissi (ca. 2650-1720 B.c.) focused on a more complete characterization of the complexity and variation in Minoan funerary practices. Using archaeothanatology and involving field anthropologists from the first stages of excavation, precise and reliable interment sequences and (successive) treatments of the bodies were reconstructed. The result is a more nuanced understanding of primary and secondary burials and in turn contemporary Minoan society.
\end{abstract}

Keywords: Bronze Age, Minoan, Crete, archaeothanatology, Sissi, funerary practices

\section{Introduction}

The appearance of intensive, formalized funerary practices on Crete, in caves and rockshelters during the Final Neolithic period (FN IV; ca. 3300-3000 B.C.) (Tomkins 2007) and in built cemeteries and tombs from the beginning of the Early Bronze Age (Early Minoan I [TABLE 1]; Tomkins and Schoep 2010; Tomkins 2013) raises a number of questions concerning the population occupying this region, its social organization and its funerary practices. Excavations of Early and Middle Bronze Age cemeteries on Crete began early in the 20th century (e.g., Dawkins 1900-1901; Seager 1912; Xanthoudides 1924) and since then, numerous hypotheses have been put forward concerning the social organization of Minoan society based on the treatment of the deceased and the types, sizes and organization of the tombs (e.g., Soles 1992; Branigan 1998; Papadatos 2005; Driessen 2010; Murphy 2011).

Early Bronze Age funerary loci comprise a variety of types, some exploiting natural places in the landscape, such as rockshelters and caves, others taking the form of artificial constructions, such as cist-grave cemeteries,

Correspondence to: Isabelle Crevecoeur, UMR 5199 - PACEA/Université Bordeaux 1, Bâtiment B8, Avenue des Facultés, 33405 Talence Cedex, France. Email: i.crevecoeur@pacea.u-bordeaux1.fr round (tholos, pl. tholoi) tombs and housetombs (Xanthoudides 1924; Soles 1992; Branigan 1993; Davaras and Betancourt 2004). Tholos tombs, which consist of a main round structure with rectangular annexes, were used beginning in EM I and occur mainly in south-central Crete (Branigan 1993; Relaki 2004; Alexiou and Warren 2004; Legarra Herrero 2009, 2011; Vassilakis et al. 2010; Girella in press). House tombs, which are rectangular structures consisting of one or more compartments and which resemble contemporary house plans (Vavouranakis 2007; Wilson 2008), seem to begin in EM IIA and are mostly found in the northern and eastern parts of the island (Branigan 1970b; Soles 1992; Tsipopoulou 2012; Schoep in press). Both types continued to be used in the Middle Minoan (MM) I-II period. Tholoi are occasionally found in eastern Crete (Branigan 1993; Papadatos and Sofianou 2012) and rectangular structures can occur in some tholos cemeteries (e.g., at Koumasa, Platanos) (Legarra Herrero 2011). The cemetery of Archanes Phourni in north-central Crete combines both traditions: it contains tholoi and housetombs (Sakellarakis and Sakellarakis 1991 and 1997).

It is widely believed that these early funerary foci have "collective deposits" meaning that they contain multiple individuals that were not necessarily interred at the same 
Table 1 Cretan Minoan chronology (modified following Manning 2010: Table 2.2)

\begin{tabular}{lll}
\hline Period & Abbreviation & Absolute dating (B.C.) \\
\hline Early Minoan & EM I & $3100 / 3,000-2650$ \\
& EM IIA & $2650-2450 / 2000$ \\
& EM IIB & $2450 / 2200-2000$ \\
\multirow{5}{*}{ Middle Minoan } & EM III & $2200-2100 / 2050$ \\
& MM IA & $2100 / 2050-1925 / 1900$ \\
& MM IB & $1925 / 1900-1875 / 1850$ \\
& MM II & $1875 / 1850-1750 / 1700$ \\
& MM III & $1750 / 1700-1700 / 1675$ \\
& LM I & $1700 / 1675-1470 / 1460$ \\
& LM II & $1470 / 1460-1420 / 1410$ \\
& LM III & $1420 / 1410-1075 / 1050$ \\
\hline
\end{tabular}

time, but were, rather, interred at periodic intervals (Xanthoudides 1924; Soles 1992, 2001; Branigan 1993). Despite the number of individuals found in primary positions (i.e., the skeleton is found in the place of its decomposition) (Soles 1992, 2001; Maggidis 1998), Minoan funerary practice is often described as a twostage process comprising decomposition of the body in one location followed by the deposition of the bones in the final, different, resting place (Dawkins 1900-1901; van Effenterre and van Effenterre 1963; Blackman and Branigan 1982; Branigan 1987; Papadatos 2005; Betancourt et al. 2008). The reason for this is that human remains are often discovered mixed together without clear anatomical connection, a situation often described as in secondary position. In the literature, such deposits are usually called "ossuaries" and are related to a second stage of funerary practice (Soles 2001: 243). In some cases, skulls are found gathered together in a corner of the tomb, in a container or in an adjoining space (Branigan 1970b; Sakellarakis and Sakellarakis 1991; Soles 1992). These practices are often interpreted as evidence for ancestor cults (Soles 1992; Vavouranakis 2007; Driessen 2010).

In general, in ancestor cults the final phase of this secondary stage in the interment sequence is reached when the dead are incorporated into the world of the living through their recognition as ancestors (Hertz 1907; Van Gennep 1960). This process can take various forms once the bones of the dead are free of flesh and considered to be purified. In the ethnographic literature, bones may be placed in a tomb, on an altar, or even within habitation spaces (Hertz 1907; Thomas 1982). In general, discussion of secondary burial and ancestor cult in the Minoan literature is usually based upon partial data since a detailed discussion of taphonomic and osteological data is missing from old excavations. In addition, the concept of ancestor cult is used much more loosely than is the case in anthropology and ethnography.

Taken together, the current evidence suggests some variation in the treatment of the body in EM-MM II funerary contexts in Crete with primary interment, secondary deposits and/or reorganization frequently found together in the same cemeteries and even in the same funerary spaces. While there is widespread agreement that the manipulation of bones after decomposition and the isolation of skulls can be important symbolic gestures in the treatment of the deceased, there is currently a significant lack of detailed data regarding the precise positions of osteological remains, and this complicates our understanding of variation in mortuary practices. It would be extremely valuable to be able to distinguish between secondary manipulation in connection with ancestor cults, as defined in the current ethnographic literature, and manipulation resulting from a more general reorganization of space.

The latter scenario is rarely taken into consideration, however. Indeed, the dearth of osteological information contrasts sharply with the abundant detail in which funerary architecture and grave goods are described in the literature (Watrous 1994; Legarra Herrero 2009). In order to correct this discrepancy and trace Minoan funerary practices in a more rigorous way, it is necessary to apply more meticulous techniques of excavation and recording to the human remains. This approach is all the more needed because mortuary evidence has played an important role in attempts to understand Minoan society (Soles 1988, 1992; Watrous 1994; Maggidis 1998; Sbonias 1999) and to explore the emergence of greater social complexity on Crete. Variations in tomb architecture, the value of grave goods and mortuary display have been regarded as indicative of social ranking in society. The fact that some tombs within cemeteries are built more elaborately and include rare or high value grave goods (for example the gold diadems from the cemetery at Mochlos) has been widely accepted to denote impermanent differences in social status rather than permanent hierarchical differences. Because of the nature of the published data, discussion has traditionally focused on the architecture of the tombs and the grave goods rather than the actual treatment of the body.

Our main objective here is to show, drawing from the excavations at the EM II-MM II cemetery at Sissi, that careful observation and recording of the positions, osteology and taphonomy of human remains, following the methods prescribed by archaeothanatology, produces more precise and reliable reconstructions of interment sequences and thus forms a fundamental first step towards a more complete characterization of the complexity and variation in Minoan funerary practices. The archaeothanatologial approach allows the discussion of potential social differentiation to be extended to include variation in the treatment of the body, in addition to architecture and grave goods. The Sissi cemetery excavations (Schoep 2009; Schoep et al. 2011, 2012) are among the first on Crete 
to employ physical anthropologists trained in archaeothanatology (Crevecoeur and Schmitt 2009) and are among only a handful to deploy anthropologists directly in the excavation of Cretan Bronze Age human remains. Trained anthropologists have also been employed in the excavation of Bronze Age human remains at Petras, directed by M. Tsipopoulou (Triantaphyllou 2012, in press; Triantaphyllou et al. in press), and at Livari, directed by Y. Papadatos (Triantaphyllou 2009; Papadatos and Sofianou 2015).

\section{Archaeothanatology: An Introduction}

Archaeothanatology, also called "Field Anthropology," was developed in France over the past three decades and has drastically shifted how French archaeologists approach mortuary analysis (Boulestin and Duday 2006; Duday 1987: 56). The origins of this taphonomic analysis are found in the publication of the "collective grave" (see below) of the Mournouards in the South of France (Leroi-Gourhan et al. 1962). From the late 1970s, Duday (1978 and 1987) formalized the approach by connecting the position of the skeletal remains with the original position of the body and the original interment context. The aim was to reconstruct the behavior of ancient populations towards death by understanding the management and treatment of the deceased (Duday 2009).

Archaeothanatology combines knowledge about how the human body decomposes with detailed observations of the created grave environment in order to explain the final spatial configuration of skeletal remains as found at the moment of excavation. Post-depositional processes, such as flooding, erosion, and disturbances by fauna and flora are also taken into consideration. The first step is to map, study and explain every deviation from the normal anatomical articulation of the skeleton. As such, this first step of archaeothanatology represents a new, more comprehensive way of studying interment sequences, funerary practices and treatments of the dead which do not belong to a funeral. The second step aims to determine the state of the human remains when they were taken from one location to the place where they were exhumed. The final step combines observations in the field with expertise from disciplines such as biological anthropology, ethnology and sociology in order to interpret mortuary practices.

Prior to the development of this approach, the physical anthropologist was only called in after excavation had finished. In contrast, archaeothanatology integrates physical anthropologists into the whole process, from excavation to final study. Interpretation depends on the quality of the field data, necessitating accurate records during the fieldwork since any information that is not observed and/or recorded in the field is lost forever (Duday et al. 1990; Duday 2005). Although this method has revolutionized the approach to mortuary contexts in French archaeology, until 2000 its influence beyond the French speaking world was limited by a lack of publications in English (Knudson and Stojanowski 2008). Since then, however, it has been described in several English papers (Murail et al. 2004; Peressinotto et al. 2004; Zeytoun et al. 2004) and adopted more widely (e.g., Rockandic 2002; Nilsson Stutz 2003; Willis and Tayles 2009; Knüsel 2014). Relatively few English-language publications have described the approach in detail, however (Duday and Guillon 2006; Duday 2009).

\section{Archaeothanatology: Terminology}

A primary deposit (or primary burial at Sissi) is where excavated skeletal elements are in the same place where the corpse, still in anatomical integrity, was placed and then decomposed (Duday 2009). The term secondary deposit applies when the evidence suggests that skeletal elements were partially or completely disarticulated when put in the place of discovery (Boulestin and Duday 2006). This implies that the decomposition of the corpse occurred in a separate, temporary location before the final deposition of the human remains. The distinction between these two stages is not straightforward. It should be stressed that the presence of mixed skeletal remains or the absence of a complete articulated skeleton does not automatically imply a secondary deposit because alterations to the configuration of a primary deposit may happen as a result of a variety of factors. In order to speak of a secondary deposit, it must be demonstrated that the body or the body part has been moved from its original locus of decomposition and that alterations to the configuration of the skeletal elements are related to intentional intervention by people, with all other potential sources of disturbance excluded (Duday 2009).

When moving from the descriptive to the interpretative level of analysis, a subdivision can be made among secondary deposits if it can be demonstrated that the manipulation of partly de-fleshed body parts or dry bones had been planned from the start of the mortuary practice. This notion of pre-planning defines what is called a "secondary burial" (Duday 2009; Knüsel 2014). The identification of a true secondary burial may be somewhat problematic when no other sources (ethnographic, iconographic and textual) are available to corroborate the practice and in most cases the term "secondary deposit" is favored.

The term "reduction" refers to the process of gathering/rearranging the bones of an individual within the place of decomposition (i.e., the primary deposit 
location). This gesture could, for instance, be performed to allow for the deposition of a new body. The place of deposition remains the primary burial space and the reduction is a practical gesture (Duday 2009). Multiple or group deposits may be defined as "synchronic" or "diachronic" (Rockandic 2002). A synchronic deposit is one where the individuals were buried at the same time and is called a "multiple deposit." Diachronic deposits are those where individuals were deposited successively in some sort of facility allowing for repeated access to the funerary context. These are termed "collective deposits."

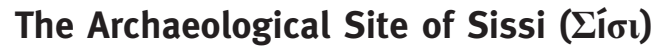

The excavations at Sissi (Crete) on the Kephali tou Agios Antoniou Hill (or Bouffo), located on the north coast about $4 \mathrm{~km}$ to the east of the palace of Malia, started in 2007 under the direction of J. Driessen (Université Catholique de Louvain, Belgium) and I. Schoep (Katholieke Universiteit Leuven, Belgium). Bouffo Hill is at the intersection of two routes between central and east Crete: the coastal route from Malia to Milatos and the inland route from Malia to Neapolis through the Selinari gorge. The cemetery is located on the northern and eastern side of the Bouffo Hill where it meets the sea (FIG. 1). When the excavation started in 2007, weathered human bones were showing on the surface closest to the sea where the impact of wind and wave erosion is strongest. At present about 30 rectangular compartments have been excavated belonging to about 12 tombs of EM II and MM I-II date. So far no activity postdating MM IIB has been identified in the cemetery, suggesting that after this point another (at present unknown) location was used, or different funerary practices took place.

The earliest material in the settlement on top of the Bouffo Hill dates to EM II and was found in secondary position, as part of fills in later structures (Driessen 2012). Nothing is known about the EM II settlement, but the cemetery of this date comprised at least one tomb consisting of multiple compartments. Fragmentary EM II pottery is also found mixed with later pottery in the cemetery, typically in secondary contexts. There is evidence of occupation during the MM IA on top of the hill (Driessen 2012) and at this time the cemetery seems to have been expanded (Schoep et al. 2011, 2012). There is evidence for the construction of multiple funerary structures between MM IA and MM II and also for the reorganization of older tombs (Schoep et al. 2012). In MM II the settlement seems to have been relatively extensive as its remains have been found in several locations beneath and to the north of Building CB in Zone 2 and Zone 5 and at the foot of the hill on its southwestern side (Driessen 2012; Devolder 2012; Jusseret 2012).

\section{Field protocols}

In the field emphasis was placed on the comprehensive recording of the sediments and of the stratigraphic units present within funerary structures. The excavation of human remains followed several steps. Following the initial exposure of human bone(s), the soil matrix was carefully scraped away

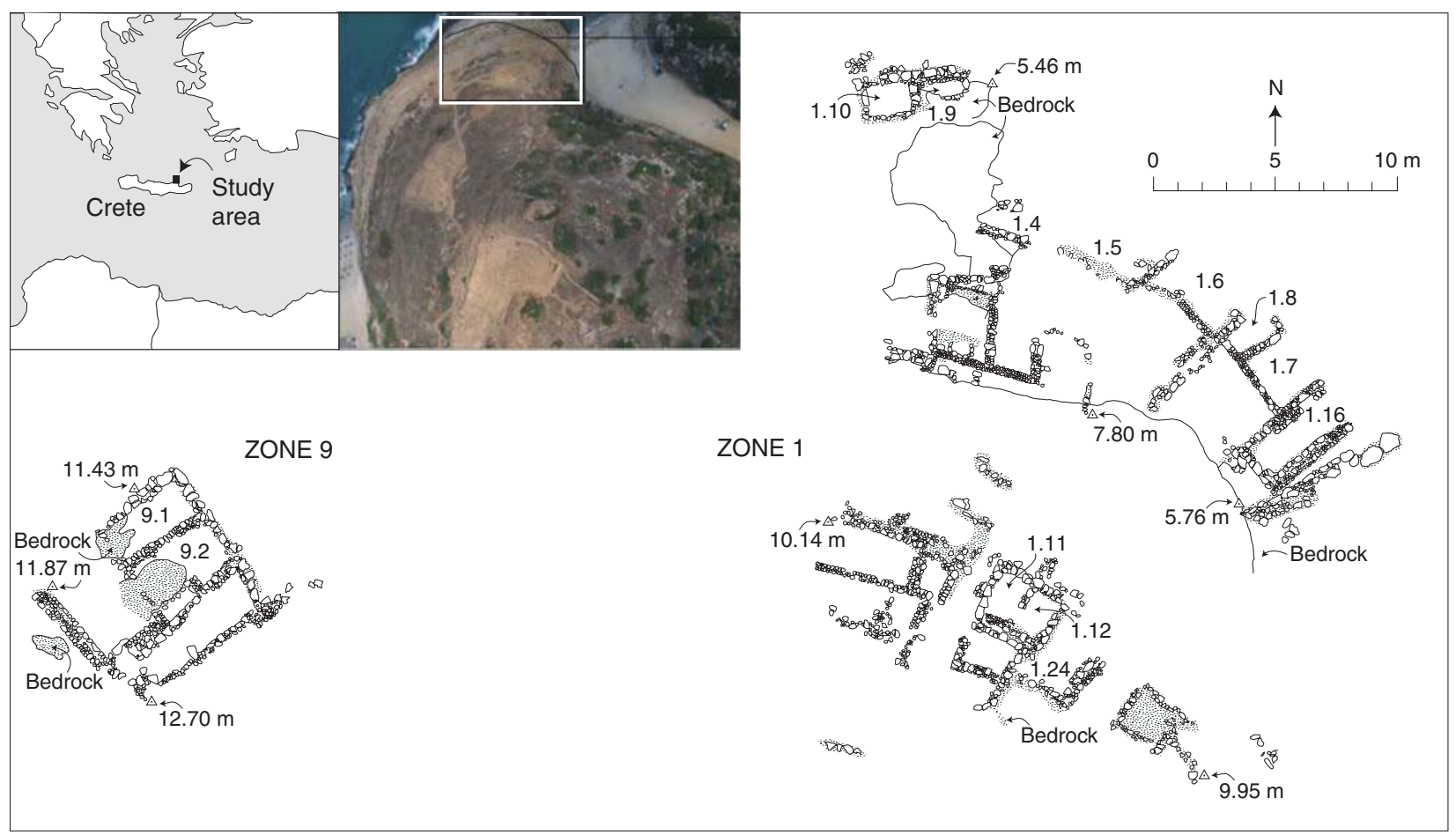

Figure 1 General plan of Zones 1 and 9 of the Sissi cemetery area. The box indicates the current limit of the cemetery area on the Bouffos Hill (c) C. Afroditi and J. Driessen. 
to reveal as much as possible of the bones without disturbing them. When scraping could not go deeper without moving the bones, the exact positions of all bones were precisely recorded and then removed. This cleaning procedure was repeated as many times as is necessary to clear a discrete assemblage of human remains.

Each cleaning phase was mapped, using scaled photography and hand-drawn plans, and a precise inventory was made of all the bones present. In addition to detailed, multi-angle digital photographic recording, photographs are taken from directly above each bone layer (zenith), at about 1.5 $\mathrm{m}$ from the bone level, with a scale, a north arrow and four reference points to allow for later correction. The zenith photographs were complemented by perspective views, which provided additional detail with regard to form and configuration. Ideally pictures were printed on site and annotated directly with the inventory numbers of the bones that were transferred during the removal phase. If this was not possible, hand-drawn plans of the bones, using graph paper, are prepared and annotated. These inventory sheets record the exact position of each skeletal fragment in three dimensions together with anatomical identification, preservation state, angle orientation and the showing up face of the bones. A total station was used to register the exact coordinates of each removed bone, along with the architecture and dimensions of the funerary structures.

\section{Post-excavation analyses}

Following excavation and recovery, all anatomical identifications made in the field were checked in the laboratory. To clarify the complexity of the deposits, drawings were made from the zenithal photographs of each removal phase with Adobe Illustrator (@ Adobe Systems Incorporated). Inventory numbers are transferred from the field drawings and a synthetic plan of all the human remains in the funerary context was produced.

The next step was to define the biological identity of the human remains, namely assessment of sex and age-at-death. The coxal bone (innominate) was used for sexual diagnosis following the visual method of Bruzek (2002). The evaluation of the age-at-death of immature individuals was based on dental and osseous maturation using standards established by Moorrees and colleagues (1963) and Birkner (1980). Immature individuals were grouped into quinquennial age classes with the exception of the youngest classes which were separated into two groups: age class $0-1$ for an age-at-death of less than a year, and age class 1-4 (Sellier 1996). As it is difficult to distinguish stillborn babies from those who survived for hours or days after birth, the term "perinatal" was used for immature individuals whose age-at-death is situated between the 7th lunar month of gestation and the 28th day after birth. In the latter case, age estimates were based on long bone measurements (Sellier 1993 in Schmitt and Georges 2008).

The Minimum Number of Individuals (MNI) was calculated for each discrete funerary structure using a multi-dimensional process. First, the most frequent elements on one side of the body were counted (White 1953). Second, this MNI of frequency was adjusted according to associations and exclusions. This refinement was made by reconstituting pairs of bones and excluding left and right elements that did not match. The final step is related to the age association, where the MNI by bone category is completed by the number of specimens for each age class that are not comprised in the most frequent bone group, but represented by other bone type. Only immature remains could be associated that way. The aim was to produce more than a simple count of individuals. This multi-dimensional characterization allowed variation in the proportions of different bone categories to be discussed. Such variations can be critical in determining differential preservation, funerary behavior or function of a funerary context (Duday 1987; Chambon 2003). Comparison of the MNI diagrams obtained for each type of bone was essential for discussing the primary or secondary nature of a deposit and the identification of human intervention (Leroi-Gourhan et al. 1962).

In a collective deposit, human remains are often disarticulated and broken up with few anatomical connections still in place. In this case, it was necessary to identify the bones belonging to the same subject by making post-excavation anatomical connections (Duday 2009). Bones were linked by pairing, stage of maturation, and articular contiguity. Following this, all the bones preserved for each individual identified were recorded and patterns in the spatial distribution of the bones in the tomb could be discussed. This process helped to identify human intervention.

\section{Archaeothanatology: four case-studies from the Sissi Cemetery}

Archaeothanatology, although slow and time-consuming, proved to be not only a highly effective means of characterizing the complexity and variation present in the human remains from the Sissi cemetery, but also a highly appropriate way of coping with their often rather poor state of preservation. We discuss below four examples that illustrate both the complexity of the deposits and the importance of integrating trained physical anthropologists into the excavation and recording process. 


\section{Primary collective deposits}

LOCI 1.11 AND 1.12

Loci 1.11 and 1.12 comprise two connecting rectangular rooms (FIG. 1), situated on an upper rock terrace in the cemetery. Preliminary study of the pottery from Loci 1.11 and 1.12 indicates an EM IIA date, which makes this the oldest funerary deposit so far identified in the cemetery (Schoep 2009). It is likely that these rooms originally formed part of a larger, multi-roomed structure; however, adjacent rooms have been heavily affected first by a later (MM I) phase of rebuilding and reuse and subsequently by slope erosion, most severely in the northern part of the rocky terrace (like for instance in Locus 1.24). During this later phase the western and southern walls of Locus 1.11 were rebuilt in a slightly different alignment. Fortunately, however, this activity left the EM IIA deposit in Loci 1.11 and 1.12 undisturbed. Later a MM interment was placed partly over this modified south wall, seemingly when it had gone out of use.

The EM IIA deposit in Locus 1.11 comprises two jars (0325/OB002, 0316/OB001) and a disturbed collective deposit concentrated on the floor in the western part of the room (FIG. 2). The human remains in this collective deposit comprise a minimum of four individuals (based on the number of humeri) among which was one adolescent (less than 20 years old, based on osseous maturation). There were no clear anatomical connections, but further study has allowed the association of several pairs of bones on the basis of their metric and morphological characteristics. One mature robust individual is better represented than the others (FIG. 3: Gray 2). A second individual is less robust and seems to have been pushed aside into the northwest corner of the room (FIG. 3: Gray 3). Every anatomical part is present, down to the smallest hand and foot bones, which suggests that these two most complete individuals form a primary deposit. The placement of the skulls together (FIG. 4) in one part of the deposit and the reorganization of the bones of one individual suggest that this location was used repeatedly for primary burials and that parts of previously buried individuals were removed and deposited elsewhere. Interestingly, on top of the deposit and embedded within the bones were found several large flat fragments of a terracotta lid. It had been placed over the bones, which were distributed in space in such a way as to suggest that they were originally contained in a perishable rectangular container. Locus 1.12 also contains the remains of one disturbed primary deposit in the north part of the room together with four jars, a conical tumbler in a fine buff clay and a lid (Schoep 2009). The pottery and the human remains were all placed on the floor of the room, which in turn rests on a fill laid to level out the underlying bedrock.

Perhaps the most significant feature of the EM IIA deposit from Loci 1.11 and 1.12 is the presence of perinatals or infants in all of the six jars found

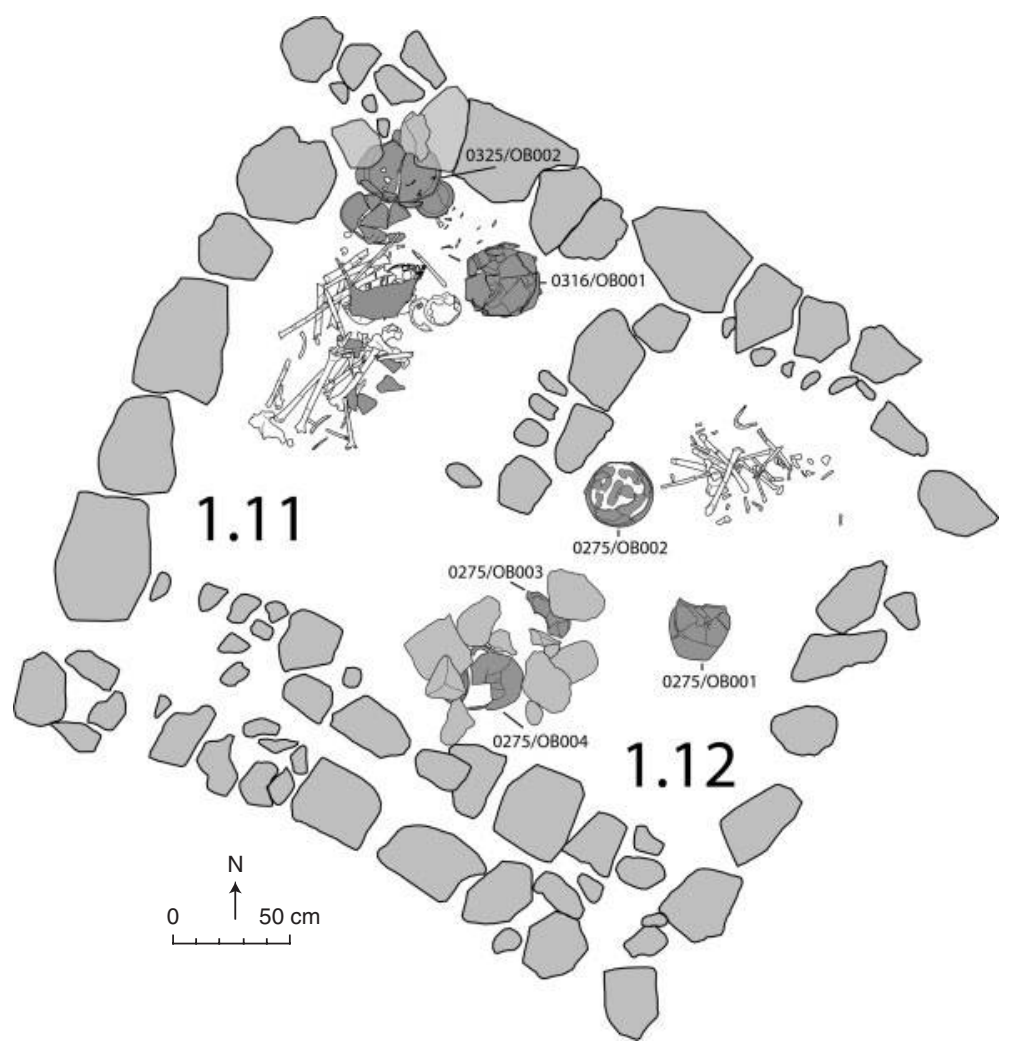

Figure 2 The remains from Loci 1.11 and 1.12. The stone walls are represented in light gray, the ceramics in dark gray. 


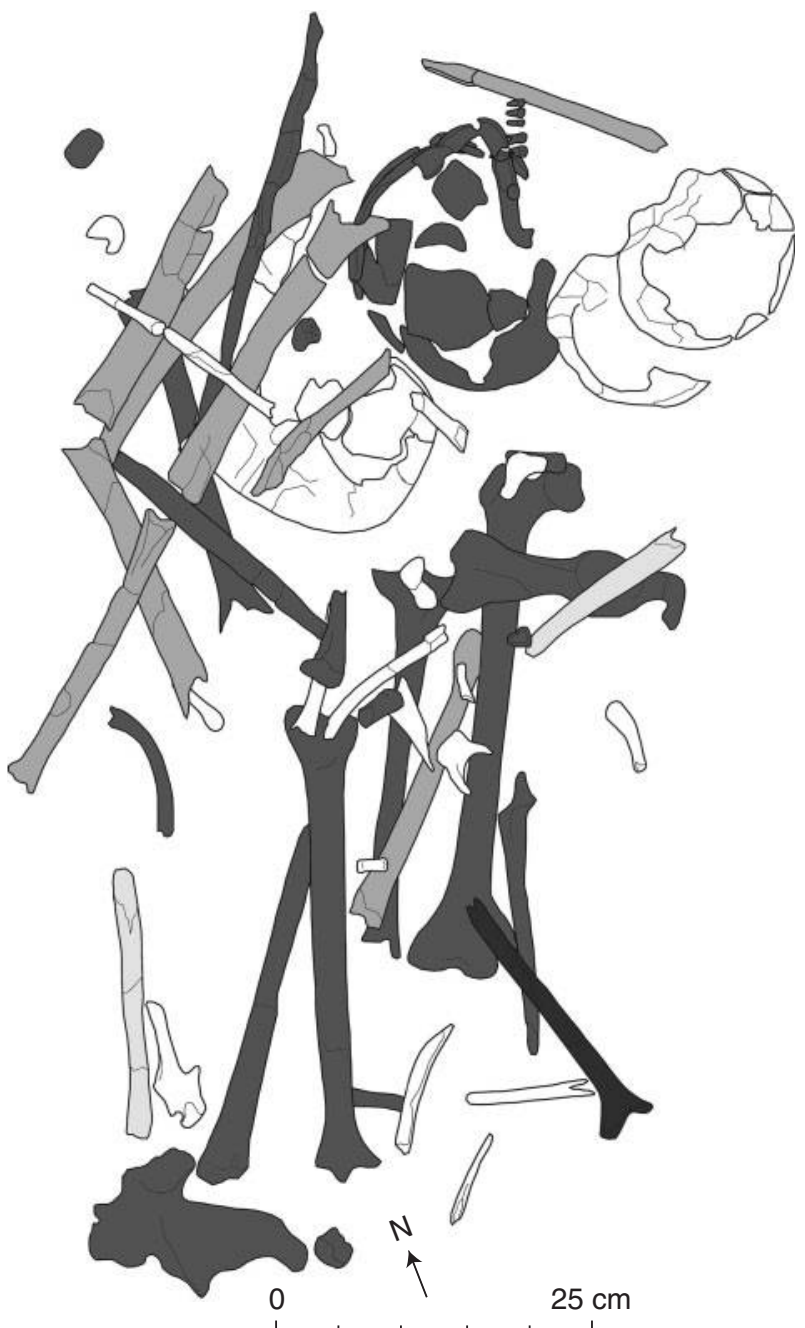

Figure 3 Close-up of the human remains from Locus 1.11 with the bones of specific individuals. The four individuals are represented by four intensities of gray from dark (Gray 1) to light (Gray 4).

in situ (FIG. 2). Four of these jars were covered with lids of some sort. The preservation of these human remains is very poor. Most of the bones were fragmented and/or encrusted. In some cases only an eroded petrous portion of the temporal bone and a few crania fragments testified to the presence of a perinatal or infant. However, the human nature of these remains is not in doubt. The bones from the hole-mouthed jar with thickened rim 0275/OB004 are better preserved. The mouth of the jar was carefully sealed with a shallow bowl and the sediment inside was different from the other jars. It was characterized by finer grains and an unusual light yellow color. In this case it is possible that the decomposition of the perinatal happened in a sealed space. Whether this was also the case for the five other jars cannot be ascertained since each of them had either a broken lid or no lid at all (0275/ OB001 \& 0275/OB003).

The identification of perinatals or infants is very important because these are normally not well

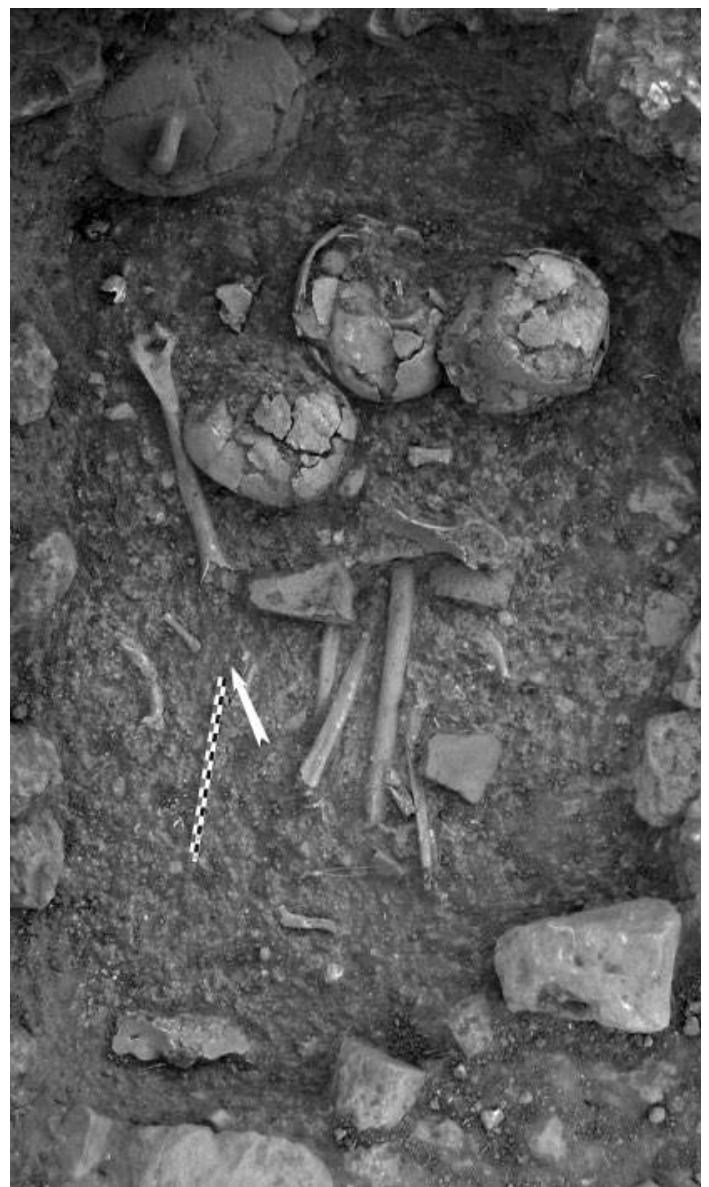

Figure 4 Locus 1.11 showing the cluster of the skulls in the northwest corner of the structure.

attested in contemporary and later Bronze Age cemeteries on Crete (Pomadère 2007; Triantaphyllou 2010). In general, "empty" vessels found during excavation of a funerary space are considered to be "grave goods" or to have formed part of funerary ceremonies involving drinking and/or eating. The possibility that they may, in some cases, have served as funerary containers has not been systematically examined. Perinatal human remains are extremely small and fragile, making them difficult to recognize and identify, and thus may well be overlooked by less careful and exhaustive methods of excavation.

\section{LOCUS 1.7}

At the heavily eroded northern and northeastern edge of the cemetery the remains of a series of rectangular spaces (Loci 1.4 to 1.8 and 1.16) were excavated. Locus 1.7 is the largest room of a two-roomed structure (Loci 1.7-1.8), built as an annex against the east wall of Locus 1.6 (FIG. 1). The southern limit of Locus 1.7 is formed by a double rubble wall of small to medium sized stones (limestone). Its northern limit is not preserved, but the edge of the rocky terrace, upon which Locus 1.7 is situated, lies only a short distance away. The human remains in Locus 1.7 
were laid directly upon a floor of small blue-gray (limestone) pebbles. Associated with these remains were cups, a worked and perforated quartz bead and a marine shell (Crevecoeur and Schmitt 2009: Fig. 4.10). Preliminary study of the pottery suggests a MM IB-II date (Schoep 2009).

Excavation in a series of cleaning phases combined with precise recording of all bones for each cleaning phase provided a very detailed picture of the spatial, stratigraphic and taphonomic relationships of each skeletal component and thereby of interment sequences and funerary practices. A minimum of seven individuals (four adults and three immature individuals) are represented (FIG. 5). Uppermost in the deposit, at an absolute elevation of 5.70 masl, were the remains of two mixed, half-complete adult skeletons (Individuals 1 and 2) as well as additional bone fragments (0117/001 and 0119/001) that do not belong to either of the two individuals (FIG. 6). Individual 1 was visible on the surface before excavation and was not in anatomical connection. The upper limb of Individual 1 was lying on top of Individual 2 , and his mandible and two femurs had been displaced by erosion. The pelvic girdle and the two femurs of Individual 2 had also been displaced in relation to the upper part of the body.

The remains of Individual 2 testify to an interesting funerary practice. The upper part of the body is clearly in primary position. Strict and loose anatomical connections are preserved (the left clavicle and the left scapula and the left humerus and the scapula). In addition, the position of the mandible and of the right clavicle and the displacement of some hand bones and teeth beyond the space originally occupied by the body suggest that decomposition took place in an empty space. More unusual is the position of the right and left tibias (0133/001 and 0133/006) and of the left fibula (0135/002) (FIG. 6). They were placed on either side of the upper part of Individual 2's body with their medial faces showing up and their distal extremities oriented toward the head. The right fibula is missing, while the left fibula is in correct anatomical position in relation to the left tibia (0133/001 and 0135/002). This suggests an intentional displacement of the lower part of the leg of Individual 2 before the body had completely decomposed. This displacement preceded the deposition of Individual 1 and might

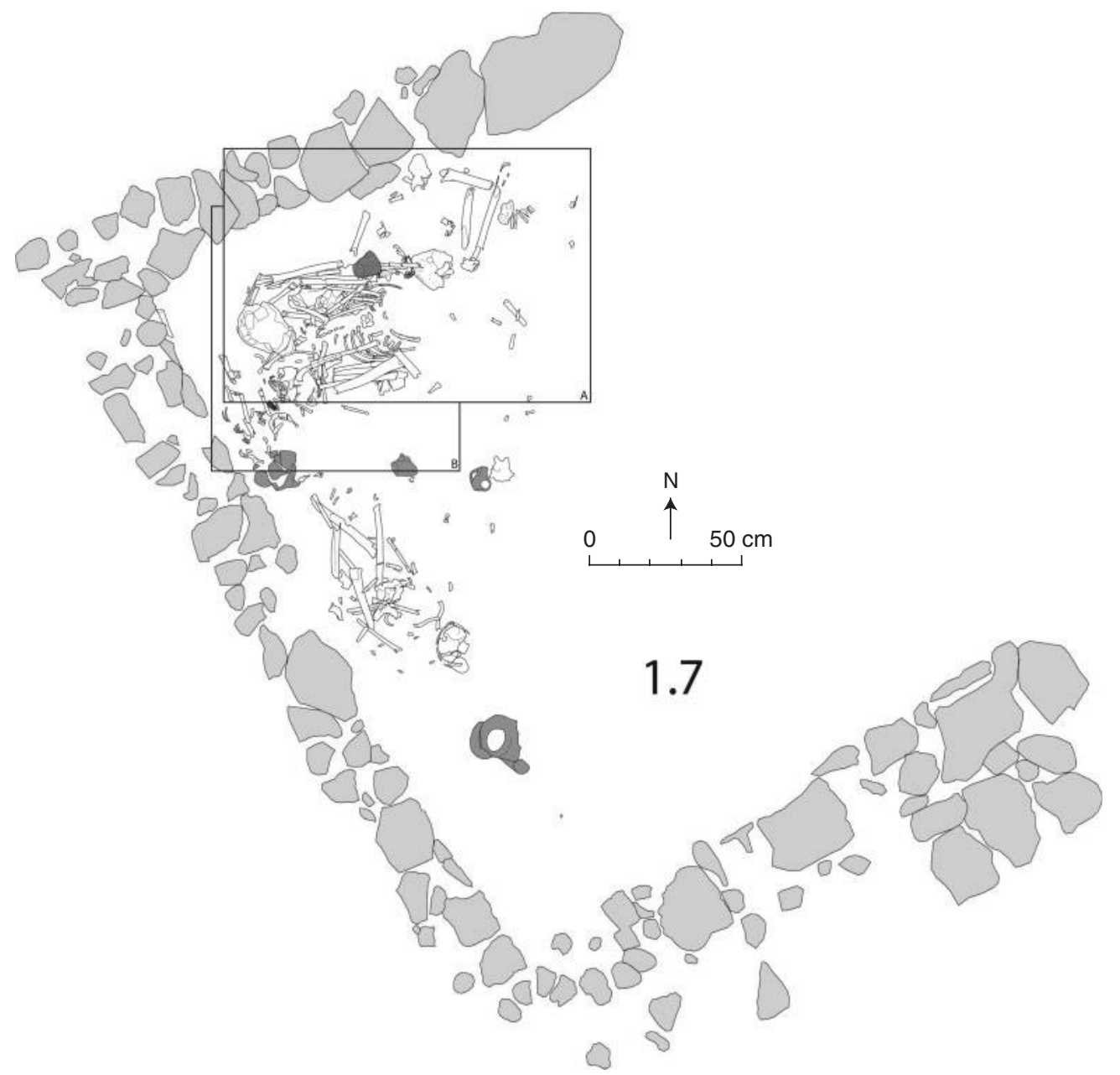

Figure 5 The remains from Locus 1.7. The stone walls are represented in light gray, the ceramics in dark gray. Rectangles (A and B) show the areas detailed in FIGS. 6 and 7. Individual 3 is represented by the remains outside of rectangles $A$ and $B$. 


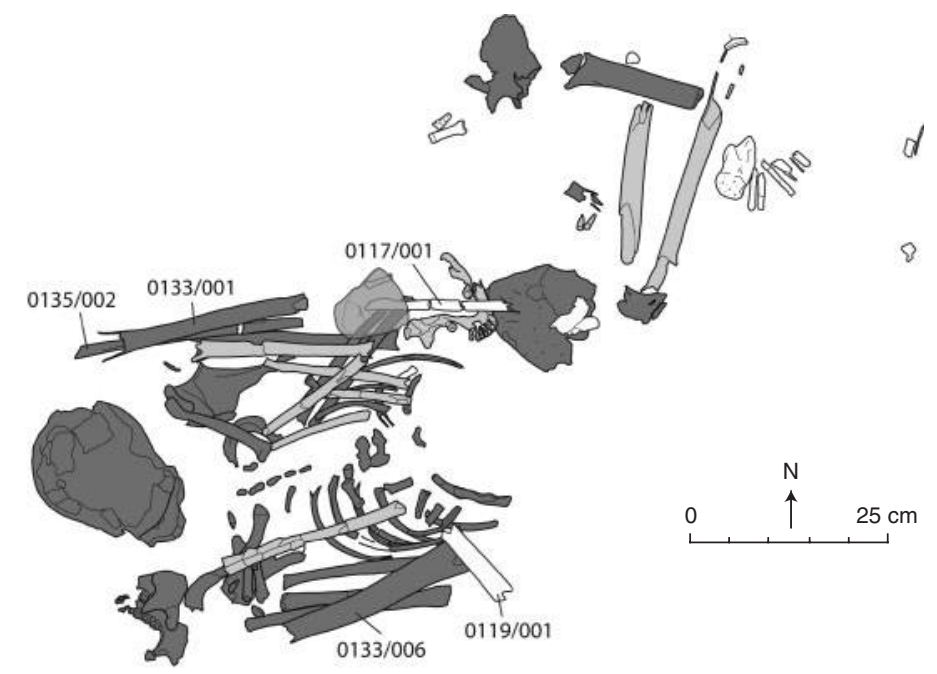

Figure 6 Close-up of area "A" from Locus 1.7 showing the attribution to specific individuals of the human remains from the upper level of deposition. Individual 1 is illustrated in light gray. Individual 2 is shown in dark gray.

possibly be associated with reorganization of the space prior to its deposition.

At the base of the deposit (at 5.58 masl), three incomplete skeletons were found lying directly on a pebble floor. Post-excavation study identified two immature individuals (Child 1 and 2) and one mature skeleton (Individual 3 remains located outside of rectangle A and B in Figure. 5 in the southern part of the locus 1.7) to be identified (FIG. 7). An additional immature femur (0167/SA009) was also found on the pebble floor underneath a large stone. The age-at-death of the two children is very close. Based on dental maturation stages (Moorrees et al. 1963), Child 1 was between 3 to 4 years old while Child 2 was a little bit older, between 4 and 5 years old. Moreover, there are indications, in the

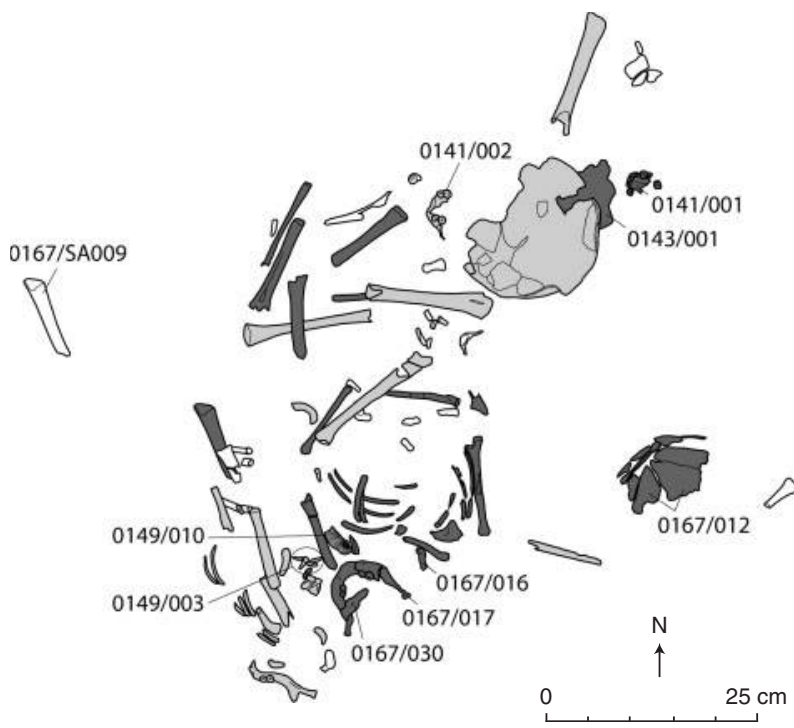

Figure 7 Close-up of area "B" from Locus 1.7 showing the attribution to specific individuals of the human remains from the lower level of deposition. Child 1 is illustrated in dark gray. Child 2 is shown in light gray. form of a series of specific shared traits (e.g. welldeveloped carabelli tubercules, shovel-shaped incisors), that the two children exhibit a potential genetic relationship and may thus have been closely related.

Several taphonomic observations can be made about these two immature individuals. First Child 1 is less disrupted and the upper part of the body is in anatomical congruity that is its skeletal components are found in close anatomical connection. The child was found lying on its back, with its forearms on the thoracic cage and a well-preserved marine bivalve shell (Arca noae) (Linnaeus 1758) was found just under its left shoulder, between the left scapula and the left humerus (149/010 in FIG. 7). Two large stones had been placed on the upper part of the scapular girdle and covered up a fragment of a cervical vertebra $(0167 / 016)$, the mandible (0167/017), which had been broken in situ, and a fragment of the left petrous portion of the temporal bone $(0167 / 030)$. The other parts of the cranium were found scattered within the deposit (e.g., 0141/ 001; 0143/001; 0167/012) (FIG. 7). The position of the left petrous bone over the mandible indicates that the cranium of Child 1 had been moved prior to the placement of the two stones and at a time when the body was already decomposed. Child 2 is represented by a more complete cranium, its upper limbs, part of the trunk and the mandible. These were found placed along the western wall of the compartment in a manner (reduction) consistent with displacement to make room for Child 1. The presence of a maxillary deciduous tooth belonging to the cranium (0141/002) in a separate group of fragments (0149/003) suggests that the skull of Child 2 was also moved after the decomposition of the body.

In this way the following deposition sequence can be reconstructed for the two children in Locus 
1.7. First, Child 2 was laid out on the pebble floor and decomposed completely. Then its skeletal remains were moved and placed along the west wall probably to make space for the deposition of Child 1. Subsequent human intervention caused the displacement of the crania of both children and their lower limbs to be mixed. Finally, after its skull had been displaced, the body of Child 1 was partially covered by two stones. The only evidence of a primary planned gesture relates to the deposition of a marine shell between the left arm of Child 1 and its body.

\section{Secondary deposits}

Locus $\mathbf{1 . 9}$

At the northern edge of the cemetery, two, small, adjoining walled spaces, Loci 1.9 and 1.10 , were found to have survived heavy erosion in this area (FIG. 1). Locus 1.9 is a small rectangular, walled compartment $(1.8 \times 0.75 \mathrm{~m})$ built directly on the bedrock. Its northern wall is a double wall, part of which comprises the eastern continuation of the northern wall of Locus 1.10, which adjoins Locus 1.9 to the west and which contained a collective burial (Schoep 2009). The northern face of the north wall is made of limestone blocks, while its internal facing in Locus 1.9 is constructed of small fieldstones. Numerous medium sized stones were found on top of the human remains in Locus 1.9 suggesting that the upper part of this north wall may have collapsed into this space (Schoep 2009). The soil matrix between these collapsed stones comprises fine and light-brown sediment. An unusual feature of Locus 1.9, and one with consequences for its dating, was the absence of any accompanying pottery, whether completed vessels or reworked fragments. A probable terminus post quem of MM IA is suggested by the presence of several handmade straight-sided cups, of MM IA type, in Locus 1.10 and against the outer northern face of the north wall of Locus 1.9 (Schoep et al. 2011).

Excavation and study revealed that the skeletal remains were not in primary position (no connection or anatomical congruity) (FIG. 8). There does, however, appear to be a relationship between the deposition of the bones and the natural topography of the bedrock "floor" of Locus 1.9. In the western half of Locus 1.9, where the bedrock is relatively level, the long bones are oriented east-west. It is also in this area that more bulky bones with complex shape, like the coxal bones, are located. In contrast, in the eastern half, the long bones are oriented north-south, following the slope of the bedrock in this area. Finally, the skulls were found placed in the northern part of Locus 1.9, where the bedrock is also relatively level.
The MNI based on frequency and exclusion accounts for at least 13 individuals: 9 adults whose sex could not be assessed, 2 children (age classes 14 and 1-4/5-9), 1 adolescent (age class 15-19) and 1 perinatal. Skulls were the most represented skeletal parts (11 individuals) (FIG. 9). The state of preservation of the crania is very poor and there is a deficit in the absolute quantity of recovered teeth compared to the quantity expected from the 11 individuals represented by skulls. As the age-at-death estimations are mainly based on dental remains, without these elements, it is extremely difficult to distinguish between fragments of skulls belonging to old children (age class 10-14), adolescents (age class 15-19) or adults. On the basis of the isolated maxillary molars, the presence of two individuals in addition to those attested by the skull remains, is indicated: a second child (age-at-death between 2 and 4 years and seven months) and an adolescent.

Some small bones, such as carpals, metacarpals and phalanges, are present but proportionally underrepresented (i.e., 12 metacarpal diaphyses, 12 hand phalanges). It is unlikely that the absence of these bones is related to erosional processes since well-preserved perinatal remains are present in the deposit. This raises the question of whether these few small bones were brought to Locus 1.9 as the result of a specific selection of this type of bone or through the transfer of a body part (for instance the upper limb) that had not completely decomposed. Support for the latter is provided by the existence of a loose anatomical connection between a craniofacial complex and the first two cervical vertebrae (atlas and axis). Indeed, the atlanto-occipital joint is among those more resistant to disarticulation. Its preservation implies that the head was moved despite the fact that it was still partly attached to the neck. A femur and a coxal bone, also a persistent joint (see Duday 2009: 26), were found in strict anatomical connection indicating that the ligaments had not decomposed at the time of deposition in this context. Study of pairing suggests that individuals are generally represented by several bones, but that the collection and transfer of skeletal remains was not exhaustive. Therefore the underrepresentation of hand bones and the absence of foot bones could be related to the labile nature of these joints, which are characterized by quick disarticulation. While the spatial distribution of paired bones suggests sometimes some clustering, it is not systematically the case. Therefore, the pre-planned nature of this organization can not be defended for the whole deposit.

In the eastern half of Locus 1.9 the remains of a perinatal individual, comprising a craniofacial complex, a humerus, a femur, 2 ribs, 2 metacarpals and 1 metatarsal, 


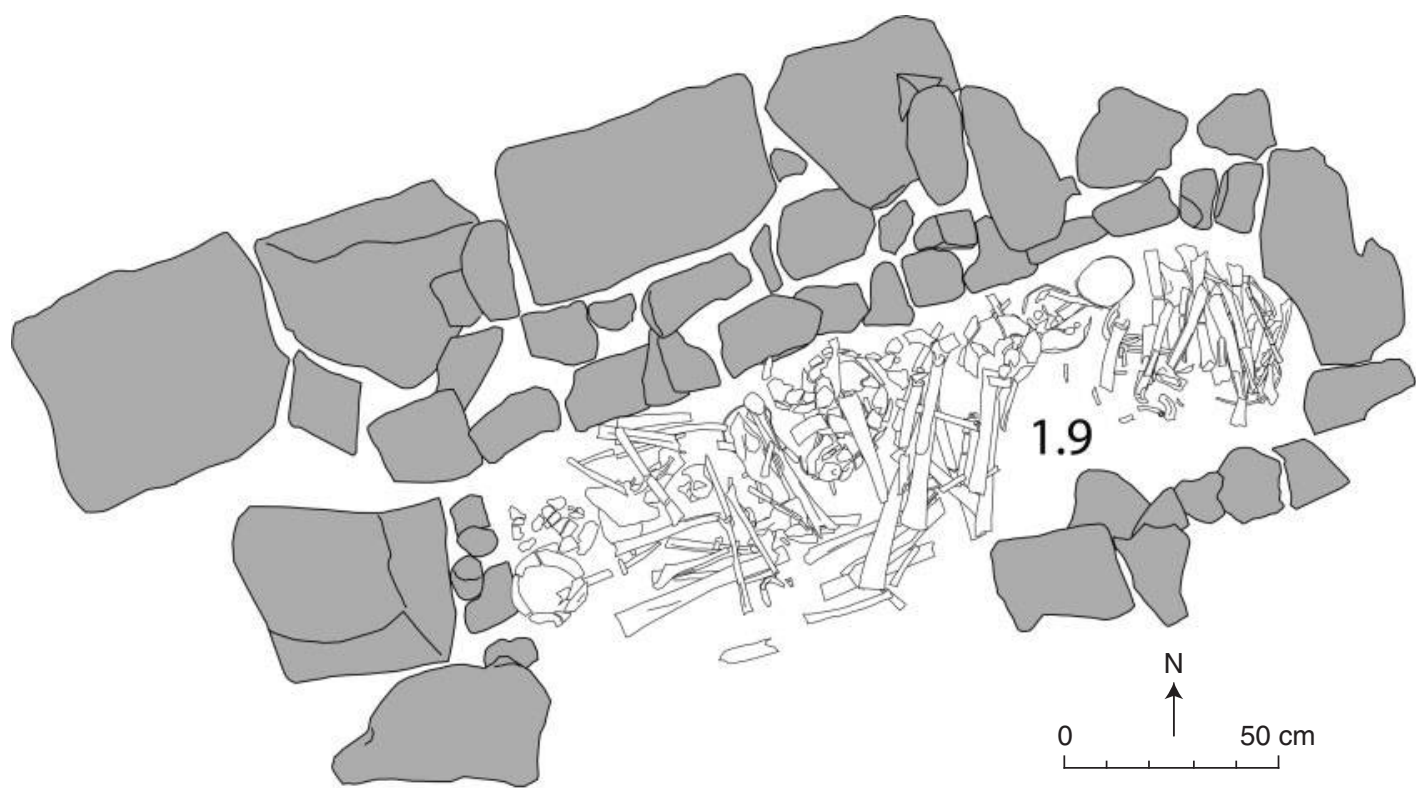

Figure 8 The remains from locus 1.9. The stone walls are represented in light gray.

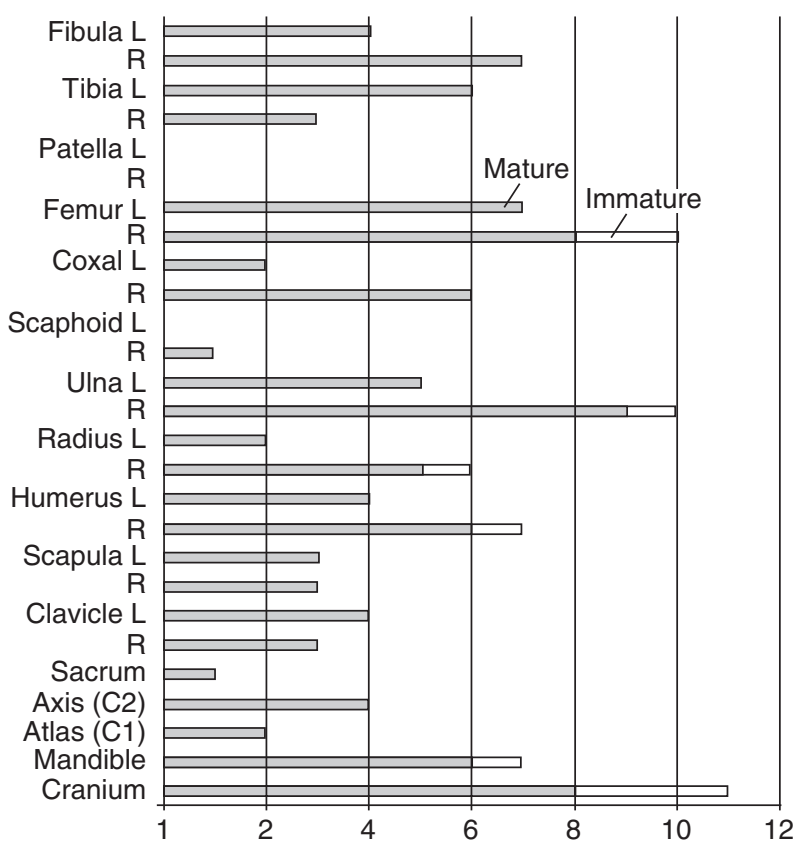

Figure 9 Osteological profile of the remains from Locus 1.9. Carpal and tarsal bones were not represented as they are absent (except for one right scaphoid). As the left/right sides of the 12 metacarpals and 12 hand phalanges could not be identified, they are not represented either.

were found gathered together. On the one hand, the fragility of the bones and their small size would seem to argue against this being a secondary deposit. On the other hand, the fact that these perinatal remains are incomplete and lack anatomical connection would seem to indicate a secondary deposit. For this to be a primary deposit, one would have to account for how it came to be disturbed and partially displaced. Successive deposition(s) of larger bones (e.g., long bones, innominate bones, craniofacial complexes, scapulas) in this part of Locus 1.9 could account for the disturbance. The absence of a significant portion of the perinatal from Locus 1.9 is more difficult to account for, however, especially in view of the meticulous nature of its excavation which made it unlikely that surviving fragments were missed. Also relevant here is the fact that the perinatal remains were found gathered together, rather than spread over a larger area, and thus do not appear to have been significantly dispersed by subsequent depositional activity. If, as seems likely, the perinatal was a secondary deposit, one still has to account for how such small and fragile bones could have been transferred from elsewhere. One obvious explanation for this is to suppose that the primary deposit of the perinatal occurred elsewhere, but that the body was only partially decomposed when moved to the second location.

Thus it may be concluded that Locus 1.9 contained a complex secondary deposit of human skeletal material. On the one hand, the majority of the human remains exhibit no anatomical connections and thus were most probably displaced after complete decomposition. On the other hand, there are also some connected elements, which together with the presence of small bones, implies that some movement of body parts took place before full decomposition had been achieved. These skeletal remains were placed in Locus 1.9, sometimes in obvious (parallel) orientation to one another. Every individual is represented by more than one bone, but the collection of bones from the place of primary deposition was clearly not exhaustive, with skulls and other larger bones, such as coxal bones, favored. Interestingly, secondary treatment in Locus 1.9 seems to have deliberately excluded other categories of material, most notably pottery, which normally form part of the primary deposits in Sissi cemetery. Also relevant here is the fact that deposition in Locus 1.9 took place directly on the natural, 
uneven bedrock, rather than on the prepared floors (e.g. clay, pebble) that typify primary deposits in the Sissi cemetery.

\section{LOCUS 9.1}

Perched on the edge of a rocky terrace at the western edge of the cemetery is a large, multi-roomed structure, of which two rooms, Loci 9.1 and 9.2, have been investigated (FIG. 1). The walls of Loci 9.1 and 9.2 have an external face of fairly large blocks and an internal face of small stones. In addition a north-south stone feature, possibly a wall, divides Locus 9.1 into eastern and western parts (Schoep et al. 2011). The bedrock of Locus 9.1 was covered by a levelling layer containing pebbles and small stones. The rest of the deposit is composed of seven primary burials, grouped in the eastern half of Locus 9.1, and one possible secondary burial in its southwestern corner.

The primary nature of the deposits in the eastern half of Locus 9.1 is obvious for Individuals 4 and 6. In the other cases, it was only through detailed, in situ analysis of the remains that it was possible to reconstruct the timing of deposition of this collective burial and to understand the observed disturbances. In the northeastern corner, Individual 1 was installed in a pithos (the upper part of the body is in anatomical connection) (FIG. 10) and disturbed later by the deposition of Individual 4 , a woman in a contracted position. The disturbance is characterized by the displacement of the right foot against the northeastern wall, on which has been placed the left lower limb that was still in partial anatomical connection. These observations imply that the reduction of some part of Individual 1 was done before it had entirely decomposed. This first set of events was sealed off by a layer of sediment above which were deposited three adult individuals: Individual 3 (a woman) and Individuals 5 and 6 (men). Individual 3 was lying on her back with hands in front of her face and the lower limbs in a contracted position. The preservation of the labile connection between the right scapula and humerus testify to a primary deposition. Individual 5 was lying on his right side. The primary nature of the deposit can be determined notably by the persistence of connections between the labile carpal articulations. Individual 6 was lying on his left side in a contracted position and associated with several pots. Finally, Individual 5 was partly truncated to lay out the pebble floor upon which Individual 2 was deposited in a contracted position. Most of these individuals are incomplete because subsequent depositions have led to the removal or displacement of some of their body parts. The remaining bones are articulated and the preservation of labile joint connections confirms that Locus 9.1 was the primary place of their decomposition.

In the western half, a secondary deposition of a single individual (Individual 7), represented by a skull, long bones and hip bones (FIG. 11), was found in a pit-like deposit, comprising clay-rich dark soil, in the southwestern corner. The long bones in this deposit were grouped along the south wall, the coxal bones were positioned to the west and the cranium was placed in the center. A lamp fragment and a fragmentary tripod cup, of MM IBMM II date, were found above the bones. Study of the remains indicated that this individual was an

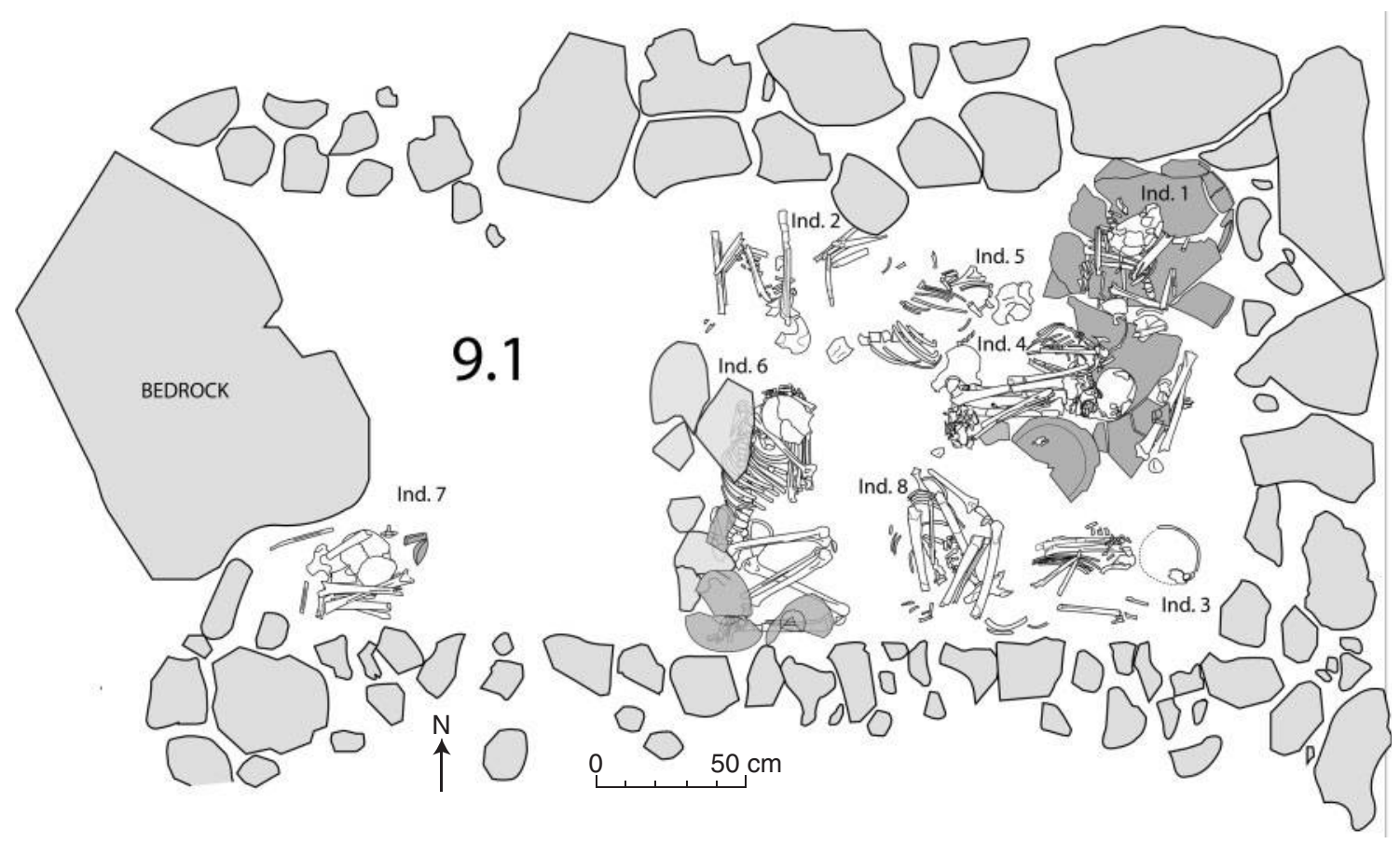

Figure 10 The remains from locus 9.1. The stone walls are represented in light gray, the ceramics in dark gray. The locations of individuals (Ind.) 1-8 are showing. 


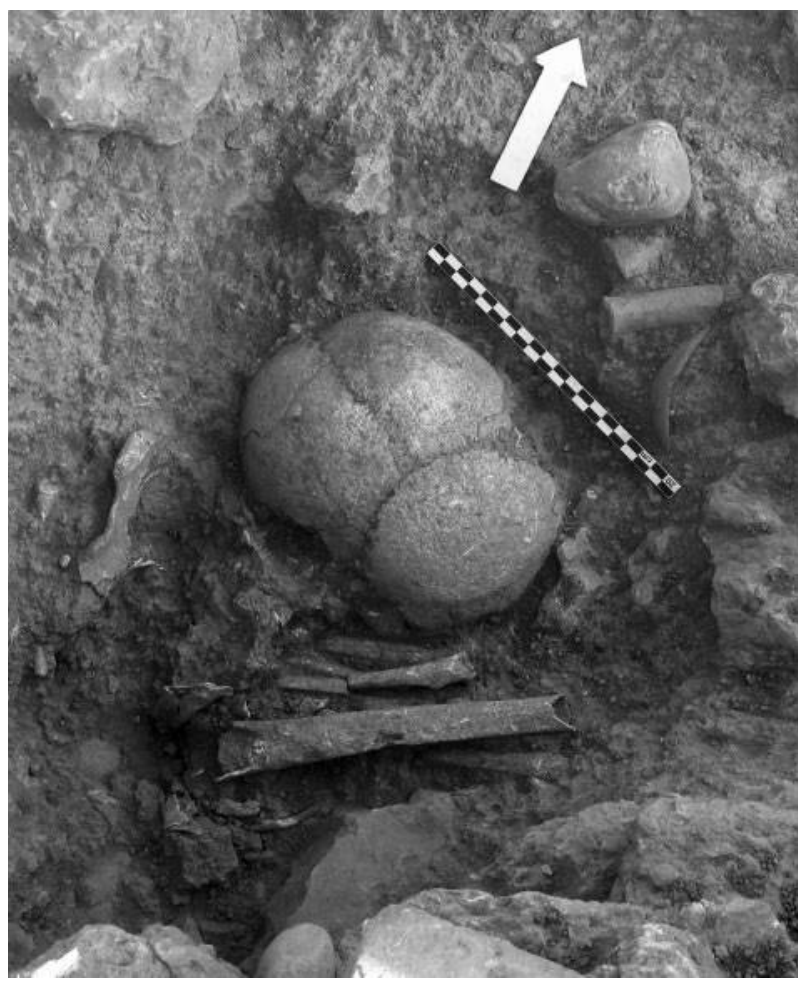

Figure 11 The secondary deposition of Individual 7 in Locus 9.1 .

exceptionally slender (gracile) adult, especially compared to the more robust nature of the individuals from the eastern half of Locus 9.1, as well as elsewhere in the cemetery.

\section{Discussion}

For decades, the absence of detailed information on the nature and taphonomy of human remains in Minoan cemeteries limited the extent to which complexity and variation in Minoan funerary practices could be reconstructed and largely restricted discussion to architectural and artifactual data (Branigan 1970a; Soles 1992; Karytinos 1998; Betancourt and Davaras 2003; Davaras and Betancourt 2004; Legarra Herrero 2009). Thus Early Minoan funerary practices are today generally considered to have been highly regionalized, based mainly on the differences in funerary architecture (i.e., round [tholos] tombs vs. house tombs vs. cist-grave cemeteries). While the general consensus is that tholos and house tombs were collective deposits, and while primary and secondary forms of deposition have been recognized, there has been little in the way of more detailed characterization of similarities and differences in the treatment of the deceased within and between cemeteries. For instance, while undisturbed primary deposits are straightforward to recognize, generally little or no distinction has been made between disturbed primary deposits and actual secondary deposits. In addition, inferences about funerary practices have rarely taken into account issues and details of taphonomy. Thus, for example, although the belief that these collective deposits relate to ancestor worship is widespread (Branigan 1993; Murphy 1998; Soles 2001; Driessen 2010), this point is currently more one of faith than a conclusion based on empirical evidence (Vavouranakis 2007; Whitley 2002). We would argue that a specific tradition of belief and practice, such as ancestor veneration, cannot simply be assumed, but must be based on reliable archaeothanatological evidence.

Both the potential of archaeothanatological characterization and the complexity of Minoan funerary practices may be illustrated by considering the new data obtained from the Sissi cemetery. The archaeothanatological analyses of Loci 1.7 and 1.9 revealed two bone assemblages that had undergone two distinctive forms of treatment. Locus 1.7 was a primary collective interment of individuals that were deposited at different times and left to decompose in situ. Careful study allowed further anthropogenic displacements of the remains to be interpreted as resulting, not from secondary deposition, but from spatial reorganization within the place of decomposition and necessitated by the introduction of new interments. Evidence for the removal of previously deposited body parts could also be observed, thus providing an important link to a secondary stage of treatment not represented in the room.

The function of Locus 1.9 proved to be distinct from that of other collective deposits in the cemetery. Aside from the southwestern corner of Locus 9.1, Locus 1.9 is the only space so identified in the cemetery that can unequivocally be associated with the secondary deposition of human remains. This small, rectangular compartment exhibits clear signs of organization: anatomical parts were selected, presumably from primary deposits elsewhere, and then carefully placed in a small compartment with consideration given to internal organization and topographical constraints.

Identification of the intentionality behind the use of Locus 1.9 is problematic. It is clearly a secondary deposit, but could it be considered to be a secondary burial? The question cannot be answered without additional evidence, and thus this location is defined as a secondary deposit. On the other hand, the secondary deposit from 9.1 is less equivocal because the place of deposition (i.e., in a collective burial), the preservation of individuality (i.e., an absence of mixing with the bones of other individuals) and the presence of several (fragmented) ceramic vessels under, next to and above the deposit are strong arguments for the sort of intentional and singular gesture associated with a true secondary burial.

Regarding the longstanding question of ancestor veneration, the Sissi cemetery data are suggestive 
but not unequivocal. Thus particular practices, such as the collecting together of skulls, are attested (e.g., Locus 1.11, as well as Locus 1.10) (Schoep et al. 2011), which recall comparable examples of skull retention from Archanes and Palaikastro (Soles 1992). In the case of Archanes, the gathering and redeposition of the skulls is accompanied by the placement of cups, which are interpreted as offerings, yet this is not the case for Loci 1.11 and 1.10.

Recognition of skull retention and skull grouping is one thing, but inferring the belief behind such practice is quite another. The gathering of skulls should not automatically be considered as evidence of ancestor veneration. Before the significance of funerary practices can be inferred, it is crucial that they are comprehensively and exhaustively characterized in the field with due attention paid to taphonomic evidence. Thus, for example, in the publication of the Archanes cemetery by Sakellarakis and Sakellarakis (1997), there is an imbalance in the engagement with the human remains; skulls receive most attention and are quantified, while long bones are only mentioned in passing without any more detailed information (regarding quantity, orientation, taphonomy). The heavy emphasis on the crania could lead to the impression that they are more represented, which could be misleading in the absence of similarly detailed data on other human bone categories. In the case of Sissi, it is only through comprehensive characterization and careful documentation of multiple examples of this practice in other collective deposits from the same time period that it becomes possible to infer that crania grouping was an intentional and pre-planned practice and exclude the possibility that this results more simply from an ad hoc reorganization of the funerary space.

The case of child interments is also instructive. It has recently been claimed that interments of children are very sparsely ( $<100$ for EM-LM I) represented in the prehistoric archaeological record from Crete (Pomadère 2007). The lack of information on the treatment of immature remains is mainly related to their small size and more fragile state and the generally limited attention paid to human remains in excavations of the early 20th century (Branigan 1970a; Soles 1992; Pomadère 2007). In addition, this scarcity of (fragile) immature human bones may also be related to continuous cycles of use, reorganization, cleaning and reuse of collective funerary spaces during the EM and/or MM periods (Triantaphyllou 2005). This situation has led to speculation regarding the place of children in funerary rituals: was there an age threshold for full integration into society and thus an age-at-death qualification for access to funerary treatment (Pomadère 2007)?
It is important to recognize that such hypotheses are based entirely on the assumption that the absence or scarcity of evidence is real.

The results from Sissi provide a more detailed picture of the treatment of immature individuals in the Minoan funerary record. They provide strong support for the hypothesis that the remains of children are not so much absent as under-recorded, partially because of their small size and fragility and partially because of their often poor preservation. The remains of perinatal or young children were found in all three of the funerary contexts detailed here and in all attested phases of the cemetery (i.e., EM IIA, MM IA, MM IB, and MM II). Also worthy of note here is the presence in Locus 1.10 of at least 10 perinatals, together with the remains of other immature, adolescent and adult individuals (Schoep et al. 2011). The perinatal/infant jar interments from Loci 1.11 and 1.12 were undoubtedly the most difficult to identify because of their small size and fragile state of preservation. Indeed, it is quite conceivable that less careful excavation and recording would have missed them entirely and would thus have interpreted the jars, not as funerary containers, but as "grave goods."

The treatment of immature individuals in the primary collective deposit in Locus 1.7 and in the secondary deposit in Locus 1.9 lends strong support to previous observations of an absence of differentiation in funerary practices between adults and children during the MM period (Pomadère 2007). Archaeothanatological characterization enabled a detailed reconstruction of interment sequences to be made in both of these locations. Thus, in the case of Locus 1.7, it was possible to clearly associate one grave good (the marine shell) with the deposition of one of the two children. Our study also allowed us to posit that both children were related on the basis of the occurrence of singular discrete traits on the reattributed first upper molars and incisors. Similarly in the case of Locus 1.9, the identification and interpretation of the immature remains within this extremely complex assemblage could not have been made without a meticulous archaeothanatological approach.

\section{Conclusions}

It has long been commonplace to use funerary practices as a means of understanding the social identities, lives and aspirations of the peoples of the past. For many decades archaeological engagement with funerary practices was mediated primarily through the study of artifacts associated with the deceased complemented, in the best cases, with biological data resulting from the examination of bones after excavation. Here we have argued that a more 
detailed, taphonomic characterization of human remains, as outlined in archaeothanatology is not simply preferable but essential to the study of Minoan funerary practices. We believe our work at the Early and Middle Minoan cemetery at Sissi illustrates the necessity of deploying trained physical anthropologists in the field, beginning with the very first stage of excavation, to produce comprehensive and detailed interment sequences from primary deposition to the moment of excavation. Only by integrating traditional archaeological expertise in the excavation and characterization of architecture and artifacts with precise, specialized excavation and characterization of human remains, does it become possible to glimpse intentional planning and interpret past funerary practices and rituals. While the recent increase in the involvement of physical anthropologists in the excavation of Minoan funerary complexes (Betancourt et al. 2008; Triantaphyllou 2009, in press) encourages us to be optimistic, we believe that future progress in Minoan cemetery studies would be best achieved through a full adoption of archaeothanatological terminology and techniques.

\section{Acknowledgments}

This study was funded by the Université catholique de Louvain (UCL, Belgium), the Fonds de la Recherche Scientifique (FNRS, Belgium), the Katholieke Universiteit Leuven (KUL, Belgium), the Fonds Wetenschappelijk Onderzoek (FWO, Belgium) and the Centre National de la Recherche Scientifique (CNRS, France), under the auspices of the Belgian School at Athens. We are grateful to J. Driessen (UCL), director of the Sissi excavation, who entrusted us the study of the Sissi cemetery and to P. Tomkins who provided thorough editing and review of the paper.

Isabelle Crevecoeur (Ph.D. 2006, Université Bordeaux 1 and Katholieke Universiteit Leuven) is a researcher at CNRS in France. Her research interests include palaeoanthropological and bioarchaeological studies of Late Pleistocene fossil specimens and Early Holocene populations from Europe and Africa.

Aurore Schmitt (Ph.D. 2001, Université Bordeaux 1, France) is a researcher at CNRS in France. Her research interests include the archaeology of death during the Neolithic and Bronze Age in the Mediterranean.

Ilse Schoep (Ph.D. 1996, Katholieke Universiteit Leuven) is a lecturer at the Katholieke Universiteit Leuven, Belgium. Her research interests include Minoan palaces, social organization, writing and administration, and funerary practices.

\section{References}

Alexiou, S., and P. M. Warren. 2004. The Early Minoan Tombs of Lebena, Southern Crete, Studies in Mediterranean Archaeology 30. Sävedalen: Paul Aströms Förlag.

Betancourt, P. P., and C. Davaras. 2003. The Pseira Cemetery II: Excavation of the Tombs. Pseira VII. Philadelphia: INSTAP Academic Press.

Betancourt, P. P., C. Davaras, H. M. C. Dierckx, S. C. Ferrence, J. Hickman, P. Karkanas, P.-J. P. McGeorge, J. D. Muhly, D. S. Reese, E. Stravopodi, and L. L. Verstegen. 2008. "Excavations in the Hagios Charalambos Cave," Hesperia 77: 539-605.

Birkner, R. 1980. L'Image Radiologique Typique du Squelette. Paris: Maloine.

Blackman, D., and K. Branigan. 1982. “An Early Tholos Tomb at Ayia Kyriaki," Annual of the British School at Athens 77: $1-57$.

Boulestin, B., and H. Duday. 2006. "Ethnology and Archaeology of Death: From the Illusion of References to the Use of a Terminology," Archaeologia Polona 44: 149-469.

Branigan, K. 1970a. The Tombs of the Mesara. A Study of Funerary Architecture and Ritual in Southern Crete, 2800-1700 B.C. London: Gerald Duckworth.

Branigan, K. 1970b. The Foundations of Palatial Crete. New-York/ Washington: Routledge \& Paul Kegan.

Branigan, K. 1987. "Ritual Interference with Human Bones in the Mesara Tholoi," in R. Laffineur, ed., Thanatos. Les Coutumes Funéraires en Egée à l'Âge du Bronze. Actes du colloque de Liège. Aegaeum 1. Liège: Université de Liège, 43-50.

Branigan, K. 1993. Dancing with Death. Life and Death in Southern Crete c. 3000-2000 B.C. Amsterdam: A. Hakkert.

Branigan, K. 1998. Cemetery and Society in the Aegean Bronze Age. Sheffield Studies in Aegean Archaeology 1. Sheffield: Sheffield Academic Press.

Bruzek, J. 2002. "A Method for Visual Determination of Sex, Using the Human Hip Bone," American Journal of Physical Anthropology 117: 157-168.

Chambon, P. 2003. Les Morts Dans les Sépultures Collectives Néolithiques en France. Paris: CNRS.

Crevecoeur, I., and A. Schmitt. 2009. "Etude Archéo-anthropologique de la Nécropole (Zone 1)," in J. Driessen, and I. Schoep, eds., Excavations at Sissi. Preliminary Report on the 2007-2008 Campaigns. Aegis 1. Louvain-la-Neuve: Presses Universitaires de Louvain, 57-94.

Davaras, C., and P. P. Betancourt. 2004. The Hagia Photia Cemetery I. Philadelphia: INSTAP Academic Press.

Dawkins, W. B. 1900-1901. "Skulls from Cave Burials at Zakro," Annual of the British School at Athens 7: 150-155.

Devolder, M. 2012. "The excavation of the open area north of Building E in Zone 5," in J. Driessen, ed., Excavations at Sissi. Preliminary Report on the 2011 Campaign. Aegis, 6, Louvainla-Neuve: Presses Universitaires de Louvain, 117-134.

Driessen, J. 2010. "The Goddess and the Skull. Some Observations on Group Identity in Minoan Crete,' in O. Krzyskowska, ed., Cretan Offerings. Studies presented to Peter M. Warren for his 70th birthday. Athens: British School at Athens, 107-118.

Driessen, J. 2012, ed., Excavations at Sissi. Preliminary Report on the 2011 Campaign. Louvain-la-Neuve: Presses Universitaires de Louvain.

Duday, H. 1978. "Archéologie Funéraire et Anthropologie," Cahiers d'Anthropologie 1: 55-101.

Duday, H. 1987. "Contribution des Observations Ostéologiques à la Chronologie Interne des Sépultures Collectives," in H. Duday, and C. Masset, eds, Anthropologie Physique et Archéologie. Méthodes d'étude des sépultures. Paris: Éditions du CNRS, 51-59.

Duday, H. 2005. "L'Archéothanatologie ou l'Archéologie de la Mort," in O. Dutour, J.-J. Hublin, and B. Vandermeersch, eds, Objets et Méthodes en Paléoanthropologie. Paris: Comité des travaux historiques et scientifiques, 153-215.

Duday, H. 2009. The Archaeology of the Dead. Lectures in Archaeothanatology. Oxford: Oxbow Books.

Duday, H., and M. Guillon. 2006. "Understanding the Circumstances of Decomposition when the Body is Skeletonized," in A. Schmitt, E. Cunha, and J. Pinheiro, eds., Forensic Anthropology and Medicine. Totowa, NJ: Humana Press, 117-157.

Duday, H., P. Courtaud, E. Crubezy, P. Sellier, and A.-M. Tillier. 1990. "L'Anthropologie de 'Terrain': Reconnaissance et Interprétation des Gestes Funéraires," Bulletins et Mémoires de la Société d'Anthropologie de Paris, N. S. 2: 29-50. 
Girella, L. in press. "Variables and Diachronic Diversities in the Funerary Remains: the Kamilari Tholos Tombs," in M. Relaki, and Y. Papadatos, eds., From the Foundation to the Legacy of Minoan Society. Sheffield Aegean Round Table in Honour of Professor K. Branigan. Sheffield: Department of Archaeology, 29-31 January 2010.

Hertz, R. 1907. "Contribution à une Étude sur la Représentation Collective de la Mort," L'Année Sociologique: 49-137.

Jusseret, S. 2012. "The excavation of Zone 6," in J. Driessen, ed., Excavations at Sissi. Preliminary Report on the 2011 Campaign. Aegis, 6. Louvain-la-Neuve: Presses Universitaires de Louvain, $135-154$.

Karytinos, A. 1998. "Sealstones in Cemeteries: A Display of Social Status?" in K. Branigan, ed., Cemetery and Society in the Aegean Bronze Age. Sheffield Studies in Aegean Archaeology 1. Sheffield: Sheffield Academic Press, 78-86.

Knudson, K. L., and C. M. Stojanowski. 2008. "New Directions in Bioarchaeology: Recent Contributions to the study of Human Social Identities," Journal of Archaeological Research 16: 397-432.

-Knüsel, C. 2014. "Crouching in fear: Terms of Engagement for Funerary Remains," Journal of Social Archaeology 14: 26-58.

Legarra Herrero, B. 2009. "The Minoan Fallacy: Cultural Diversity and Mortuary Behaviour on Crete at the Beginning of the Bronze Age," Oxford Journal of Archaeology 28: 29-57.

Legarra Herrero, B. 2011. "The Secret Lives of the Early and Middle Minoan Tholos Cemeteries: Koumasa and Platanos," in J. Murphy, ed., Prehistoric Crete. Regional and Diachronic Studies on Mortuary Systems. Philadelphia: INSTAP Academic Press, 49-84.

-Leroi-Gourhan, A., G. Baillou, and M. Brézillon. 1962. "L'Hypogée des Mournouards (Le Mesnil-sur-Oger, Marne)," Gallia Préhistoire 5: 23-133.

Linnaeus, C. 1758. Systema Naturae. Tomus I. Holmiae: Impensis direct. Laurentii Salvii.

Maggidis, C. 1998. "From Polis to Necropolis: Social Ranking from Architectural and Mortuary Evidence in the Minoan Cemetery at Phourni, Archanes," in K. Branigan, ed., Cemetery and Society in the Aegean Bronze Age. Sheffield Studies in Aegean Archaeology 1, Sheffield: Sheffield Academic Press, $87-102$.

Manning, S. W. 2010. "Chronology and Terminology," in E. Cline, ed., The Oxford Handbook of the Bronze Age Aegean, New York: Oxford University Press, 11-28.

-Moorrees, C. F. A., A. Fanning, and E. E. Hunt. 1963. "Age Variation of Formation Stages for Ten Permanent Teeth," Journal of Dental Research 42: 1490-1502.

Murail, P., B. Maureille, D. Peresinotto, and F. Geus. 2004. “An Infant Cemetery of the Classic Kerma Period (1750-1500 BC), Island of Saï, Sudan," Antiquity 78: 267-277.

Murphy, J. M. 1998. "Ideology, Rites and Rituals: A View of Prepalatial Minoan Tholoi," in K. Branigan, ed., Cemetery and Society in the Aegean Bronze Age. Sheffield: Sheffield Academic Press, 27-40.

Murphy, J. M. 2011. "Landscape and Social Narratives: A Study of Regional Social Structures in Prepalatial Crete," in J. M. Murphy, ed., Prehistoric Crete. Regional and Diachronic Studies on Mortuary Systems. Philadelphia: INSTAP Academic Press, 23-48.

Nilsson Stutz, L. 2003.Embodied Rituals and Ritualized Bodies Tracing Ritual Practices in Late Mesolithic Burials. Lund: Almqvist \& Wiksell International.

Papadatos, Y. 2005. Tholos Tomb Gamma. A Prepalatial Tholos Tomb at Phourni, Archanes (with a contribution by S. Triantaphyllou). Philadelphia: INSTAP Academic Press.

Papadatos, Y., and C. Sofianou. 2012. "Cultural Homogeneity and Diversity in Prepalatial Crete - New Evidence from the excavation of Early Minoan Cemeteries in the Siteia Prefecture," in M. Andrianakis, P. Varthalitou, and I. Tzachili, eds., Archaeological Work in Crete 2 (Proceedings of the 2nd Meeting, Rethymnon, 26-28 November 2010). Rethymnon: University of Crete, $48-59$.

Papadatos, Y., and C. Sofianou. (eds.). 2015: Livari Skiadi, A Minoan Cemetery in Lefki, Southeast Crete. Volume I Excavation and Finds (Philadelphia).

Peressinotto, D., P. Murail, B. Maureille, and F. Geus. 2004. "An Infant Cemetery of the Classic Kerma Period (1750-1500 b.c., Island of Saï, Sudan)," Antiquity 78: 267-277.

Pomadère, M. 2007. Les Enfants Dans le Monde Égéen, du Néolithique au Début de l'Âge du Fer. Unpublished Ph.D. dissertation, Université de Paris I, Paris.
Relaki, M. 2004. "Constructing a Region: the Contested Landscapes of Prepalatial Mesara," in J. C. Barrett, and P. Halstead, eds., The Emergence of Civilisation Revisited, Sheffield Studies in Aegean Archaeology 6. Oxford: Oxbow Books, $170-188$.

Rockandic, M. 2002. "Position of Skeletal Remains as a Key to Understanding Mortuary Behavior," in W. D. Haglund, and M. H. Sorg, eds., Advances in Forensic Taphonomy. Method, Theory, and Archaeological Perspectives, New York: CRC Press, 99-117.

Sakellarakis, Y., and E. Sakellarakis. 1991. Archanes. Athens: Ekdotike Athenon.

Sakellarakis, Y., and E. Sakellarakis. 1997. Archanes: Minoan Crete in a New Light. Athens: Ammos Publications.

Sbonias, K. 1999. "Social Development in Prepalatial Crete," in A. Chaniotis, ed., From Minoan Farmers to Roman Traders. Sidelights on the Economy of Ancient Crete. Stuttgart: Franz Steiner Verlag, 25-52.

Sellier, P. 1996. “La Mise en Évidence d'Anomalies Démographiques et Leur Interprétation: Population, Recrutement et Pratiques Funéraires du Tumulus de Courtesou" in J. F. Piningre, ed., Nécropoles et Société au Premier Âge du Fer: le tumulus de Courtesoult (Haute-Saône). Paris: Editions de la Maison des Sciences de l'Homme, 188-202.

Schmitt A., and P. Georges. 2008. "Quelle Démarche Suivre Pour Estimer l'Âge au Décès à Partir du Squelette ?" in P. Charlier, ed., Manuel Pratique de Paleopathologie Humaine. Paris: De Boccard, 269-280.

Schoep, I. 2009."The Excavation of the Cemetery," in J. Driessen, and I. Schoep, eds, Excavations at Sissi (Crete), Preliminary Report on the 2007-2008 Campaigns. Aegis 1.Louvain-la-Neuve: Presses Universitaires de Louvain, 45-56.

Schoep, I., A. Schmitt, and I. Crevecoeur. 2011. "The cemetery at Sissi: Report of the 2009 and 2010 Campaigns," in J. Driessen, and I. Schoep, eds., Excavations at Sissi. Preliminary Report on the 2009-2010 Excavations. Aegis 4. Louvain-la-Neuve: Presses Universitaires de Louvain, 41-68.

Schoep, I., A. Schmitt, I. Crevecoeur, S. Déderix. 2012. "The cemetery at Sissi: Report on the 2011 Campaign," in J. Driessen, and I. Schoep, eds., Excavations at Sissi. Preliminary Report on the 2011 Excavations. Aegis 6. Louvain-laNeuve: Presses Universitaires de Louvain, 27-50.

Schoep, I. in press. "The House Tomb in Context: Assessing Mortuary Behaviour in Northeast Crete," in M. Relaki, and Y. Papadatos, eds., From the Foundations to the Legacy of Minoan Society. Sheffield Round Table in Honour of Professor Keith Branigan. Oxford: Oxbow.

Seager, R. 1912. Explorations in the Island of Mochlos. Athens: American School of Classical Studies.

Soles, J. 1988. "Social Ranking in Prepalatial Cemeteries," in E. B. French, and K. A. Wardle, eds., Problems in Greek Prehistory. Bristol: Classical Press, 49-61.

Soles, J. 1992. The Prepalatial Cemeteries at Mochlos and Gournia and the House Tombs of Bronze Age Crete. Hesperia Supplement XXIV. Princeton: American School of Classical Studies at Athens.

Soles, J. 2001. "Reverence for Dead Ancestors in Prehistoric Crete," in R. Laffineur, ed., Potnia. Deities and Religion in the Aegean Bronze Age. Aegaeum 22. Liège-Texas: Université de Liège, 229-236.

Thomas, L. V. 1982. La Mort africaine: idéologie funéraire en Afrique noire. Paris: Payot.

Tomkins, P. 2007. "Neolithic: Strata IX-VIII, VII-VIB, VIA-V, IV, IIIB, IIIA, IIB, IIA and IC Groups," in N. Momigliano, ed., Knossos Pottery Handbook Neolithic and Bronze Age (Minoan). British School at Athens Special Studies No. 14. London: British School at Athens, 9-48.

Tomkins, P. 2013. "Landscapes of Ritual, Identity and Memory. Reconsidering Neolithic and Early Bronze Age Cave-use in Crete, Greece," in H. Moyes, ed., Sacred Darkness. A Global Perspective on the Ritual Use of Caves. Colorado: University Press of Colorado, 59-80.

Tomkins, P., and I. Schoep. 2010. "The Cretan Early Bronze Age," in E. Cline, ed., The Oxford Handbook of the Aegean Bronze Age. Oxford: Oxford University Press, 66-82.

Triantaphyllou, S. 2005. "The Human Remains (Appendix)," in Y. Papadatos, ed., Tholos Tomb Gamma. A Prepalatial Tholos Tomb at Phourni, Archanes (with a contribution by S. Triantaphyllou). Philadelphia: INSTAP Academic Press, 67-76.

Triantaphyllou, S. 2009. "EM/MM Human Skeletal remains from East Crete: The Kephala Petras Rockshelter, Siteia, and the Livari Tholos Tomb, Skiadi," Kentro 12: 19-23. 
Triantaphyllou, S. 2010. "The human remains," in A. Vasilakis, and K. Branigan, eds., Moni Odigitria: A Prepalatial Cemetery and its Environs in the Asterousia, Southern Crete. Philadelphia: INSTAP Academic Press, 229-248.

Triantaphyllou, S. 2012. "Kephala Petras: the Human Remains and the Burial Practices in the Rock Shelter," in M. Tsipopoulou, ed., Petras, Siteia. 25 years of excavations and studies. Acts of a 2-day conference held at the Danish Institute at Athens, 9-10 October 2010. Aarhus: Aarhus University Press, 161-166.

Triantaphyllou, S. in press. "Managing with Death in Prepalatial Crete: the Evidence of the Human Remains," in M. Relak, and Y. Papadatos, eds., From the Foundations to the Legacy of Minoan Society. Sheffield Round Table in Honour of Professor Keith Branigan. Oxford: Oxbow.

Triantaphyllou, S., Tsipopoulou, M., and P. Betancourt. in press. "Kephala Petras, Siteias: Anthropina Osta kai Tafikes Praktikes Sthn PM Vrachoskepi kai to MM Nekrotafeio," Pepragmenta tou 11 ou Diethnous Cretologikou Sinedriou, Rethymno, 21-27 October 2011. Rethymno. (http:// www.aegeussociety.org/en/index.php/past-conferences/11th-international-cretological-congress-21-october-2011/)

Tsipopoulou, M. 2012. Petras, Siteia. 25 years of Excavations and Studies. Acts of a 2-day Conference Held at the Danish Institute at Athens, 9-10 October 2010. Aarhus: Aarhus University Press.

van Effenterre, H., and M. van Effenterre. 1963. Fouilles Exécutées à Mallia: Études du Site et Exploration des Nécropoles, Études Crétoises 13. Paris: De Boccard.
Van Gennep, A. 1960. The Rites of Passage. Chicago: The University of Chicago Press.

Vassilakis, A., Branigan, K., and T. Campbell-Green. 2010.Moni Odigitria: A Prepalatial Cemetery and its Environs in the Asterousia, Southern Crete. Philadelphia: INSTAP Academic Press.

Vavouranakis, G. 2007. Funerary Landscapes East of Lasithi, Crete in the Bronze Age. B.A.R International Series. Oxford: Archaeopress.

Watrous, V. L. 1994. "Crete from Earliest Prehistory through the Protopalatial Period," American Journal of Archaeology 98: 695-753.

White, T. E. 1953. "Observations on the Butchering Technique of Some Aboriginal Peoples No. 2," American Antiquity 19: $160-164$.

Whitley, J. 2002. "Too Many Ancestors," Antiquity 76: 119-126.

Willis, A., and N. Tayles. 2009. "Field Anthropology: Application to Burial Contexts in Prehistoric Southeast Asia," Journal of Archaeological Science 36: 547-554.

Wilson, D. 2008. "Early Prepalatial Crete,' in C. W. Shelmerdine, ed., The Aegean Bronze Age. Cambridge: Cambridge university Press, 77-104.

Xanthoudides, S. 1924. The Vaulted Tombs of Mesara. Liverpool: University Press of Liverpool.

Zeytoun V., E. Gatto, H. Rougier, and S. Sidibe. 2004. "Dia Shoma (Mali), a Medieval Cemetery in the Inner Niger Delt," International Journal of Osteoarchaeology 14: 112-125. 